core of metal. 'This construction is of great value wherever the loads on a structure are small in relation to the required size, as in a fuselage, in the control surfaces and in the outer portions of the wing of an aeroplane. The advantages of this type of structure are a considerable gain in the ratio of strength to weight, and the complete stabilization of the skins right up to the point of collapse. A fuller account of adhesives in aircraft construction has been given elsewhere ${ }^{19}$.

I am greatly indebted to my colleagues at Aero Research, Ltd., as well as to Dr. J. S. Courtney-Pratt, for their assistance in preparing this article. Mr. Doble, Mr. R. D. Marsh and Dr. J. T. Martin in particular helped in devising the lecture demonstrations, and Mr. G. S. Neumann assisted me both in the lecture and by his systematic preparatory work.

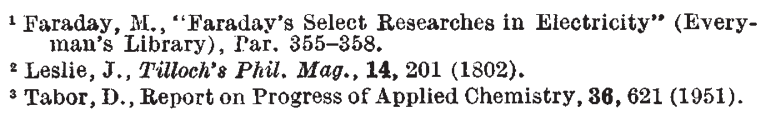

${ }^{4}$ Obreimow, J. W., Proc. Roy. Soc., A, 127, 290 (1930).

${ }^{5}$ Bailey, Anita, and Courtney-Pratt, J. S., Proc. Roy. Soc., A, 227,

'Stefan, J., Sitzb. Akad. Wiss. Wien (Math.-naturw. Kl.), 70, 713 (1874).

"de Bruyne, N. A., and Houwink, R., "Adhesion and Adhesives", 64 (Amsterdam, 1951): also Aero Research Technical Notes, Bulletin No. 24 (1944).

de Bruyne, N. A., Research, 6, 362 (1953).

'Partridge, J. H., "Glass-to-Metal Seals" (Soc. of Glass Technology, Sheffield, 1949).

${ }^{10}$ Wake, W. C., private communication.

${ }^{11}$ de Bruyne, N. A., Aero Research Technical Notes, Bulletin No. 21 (Sept. 1944).

${ }^{12}$ Browne, F. L., Indust. and Chem. Eng., 23, 290 (1931).

${ }^{13}$ de Bruyne, N. A., Aero Research Technical Notes, Bulletin No. 168 (December 1956)

${ }^{14}$ Newton Harvey, E., McElroy, W. D., and Whiteley, A. H., J. App. Phys., 18, 162 (1947).

15 Bennet, H. S., Science, 106, 646 (1947).

16 Rossman, K., J. Poly. Sci., 19, 141 (1956).

${ }^{17}$ van der Maas, H. J., J. Roy. Aero. Soc., 61, 295 (1957); see in particular Figs. 57 and 58.

${ }^{18}$ Hardrath, H. F., Leybold, H. A., et al., N.A.C.A. Technical Tote 3856 , "Fatigue-Crack Propagation in Alluminium-Alloy Box Beams" (1956).

1" de Bruyne, N. A., "Structural Adhesives for Metal Aircraft", Proceedings of the Fourth Anglo-American Aeronautical Conference (Roy. Aero. Soc., London, 1954).

\title{
OBITUARY
}

\section{Dr. L. H. Lampitt}

IN the death of Leslie Herbert Lampitt on June 3 applied science has lost an enthusiastic and inspiring personality.

$\mathrm{He}$ was born in Warwickshire on September 30, 1887, and in 1908 graduated at the University of Birmingham with double first-class honours, in chemistry and biochemistry. In 1911 he became chief chemist of La Meunerie Bruxelloise, a post which he held until the outbreak of the First World War. He served with the Army in France throughout the War.

In 1919 Dr. Lampitt began what was to be his life's work, namely, the direction of the laboratories of J. Lyons and Co., Ltd. To understand the part that science could play in a great food firm required vision in those days, and the present fine laboratories and service-rapidly developed from humble beginnings under his guidance-are a tribute to the creative genius and foresight of their founder. $\mathrm{He}$ became a director of the firm in 1936 .

Dr. Lampitt was keenly interested in new scientific and technological developments and would travel any distance to investigate new processes or to discuss mutual problems with scientists abroad. It is not surprising, therefore, that he became an international figure in the world of chemistry. He was particularly active in the International Union of Pure and Applied Chemistry, of which he had been honorary treasurer since 1945, and in the past decade he served on a number of Unesco and other international committees. $\mathrm{He}$ was also chairman of the organizing committees of several international scientific congresses, including that of surface activity held in London in the spring of this year. During recent years the international aspects of chemical documentation also claimed his attention.

In Great Britain, Dr. Lampitt had been honorary secretary of the British National Committee for Chemistry, chairman of the Chemical Council, chairman of the Bureau of Abstracts, and had held office in many of the scientific societies of which he was a member.

His greatest activity was in the Society of Chemical Industry, of which he was a past-president. At the time of his death, he had been honorary foreign secretary of that Society for a number of years. In 1932 he stimulated the formation of the Food Group of the Society and became its first chairman, and in 1951 he became first chairman of the Society's Overseas Section, which was also formed as a result of his enthusiasm. He was awarded the Society's Medal in 1943 and was the first recipient of the Society's International Medal in 1950. He received the Royal Society of Arts Silver Medal in 1947 and the Lavoisier Medal of the Société de Chimie Industrielle in 1950. He had held a number of lectureships and had published numerous papers on chemical and biochemical subjects.

Dr. Lampitt was a freeman of the City of London and a liveryman of the Worshipful Society of Apothecaries of London and of the Worshipful Company of Horners.

Although Dr. Lampitt was always at heart a scientist, he had a number of other interests. Hand in hand with his seience went his religion. During his Brussels days he was a licensed lay reader and held office in the English Section of the Y.M.C.A. ; at the time of his death he had been vicar's warden at the Church of St. Mary-on-the-Hill, Harrow, for many years.

In his younger days Dr. Lampitt was a keen sportsman, playing for his University in the football and cricket first elevens. He never lost his interest in drama, both amateur and professional, and was $a$ devoted gardener. He took great pleasure in hospitality and was a delightful host.

Dr. Lampitt will be remembered by his friends all over the world for his humanity and good fellowship and essential kindliness, no less than for his scientific achievements. $\mathrm{He}$ is survived by his wife and his son.
E. B. Hugres 